\title{
Evaluation of biologically active substances promoting the development of or protecting against endometrial cancer
}

This article was published in the following Dove Press journal:

OncoTargets and Therapy

\author{
Aneta Cymbaluk-Płoska' \\ Anita Chudecka-Głaz' \\ Anna Jagodzińska' \\ Ewa Pius-Sadowska ${ }^{2}$ \\ Agnieszka Sompolska- \\ Rzechuła ${ }^{3}$ \\ Bogusław Machaliński \\ Janusz Menkiszak' \\ 'Department of Gynecological \\ Surgery and Gynecological Oncology \\ of Adults and Adolescents, Pomeranian \\ Medical University, Szczecin, Poland; \\ ${ }^{2}$ General Pathology Department, \\ Pomeranian Medical University, \\ Szczecin, Poland; ${ }^{3}$ Department of \\ Statistics, West Pomeranian University \\ of Technology, Szczecin, Poland
}

Introduction: Adipose tissue is considered an endocrine organ and produces a number of biologically active substances.

Aims: To consider the role that four adipokines - leptin, omentin-1, vaspin, and galectin-3 - play in the diagnosis of endometrium cancer and to investigate the association between serum concentrations of adipose tissue metabolism products and the diagnostics and prognosis in endometrial cancer.

Patients and methods: The study included 168 patients with body mass index (BMI) $>20 \mathrm{~kg} / \mathrm{m}^{2}$ admitted due to post-menopausal bleeding.

Results: A receiver operating characteristic curves test was performed to determine the diagnostic values of the proteins tested. For leptin and galectin-3 the area under the curve (AUC) values were $0.79 / 0.68$, while for vaspin and omentin- 1 the AUC values were $0.82 / 0.86$ for all study patients. The final model identified the following independent risk factors: glucose concentration, BMI, waist circumference, leptin, and vaspin concentrations. Diagnostic values of leptin and galectin-3 with regard to differentiation between high (Fédération Internationale de Gynécologie Obstétrique [FIGO] III and IV) and low (FIGO I and II) stages of clinical tumor advancement and prediction of tumor grading (G1 vs G3) based on the AUC curve were $0.82 / 0.70$ and $0.80 / 0.74$. The AUC values for vaspin and omentin- 1 with respect to differentiation between histopathological advancement and grading were $0.86 / 0.81$ and $0.83 / 0.77$, respectively. Significantly lower values of mean omentin- 1 and vaspin concentrations were also demonstrated in cases of lymphatic vessel invasion, lymph node metastases, or deep endometrial infiltration ( $p=0.002, p=0.01, p=0.003$, respectively).

Conclusion: It appears that elevated concentrations of leptin, vaspin, and omentin-1 may indicate the presence of endometrial cancer. Furthermore, leptin serum level and vaspin appear to be useful tools in the assessment of clinical staging of endometrial cancer.

Keywords: endometrial cancer, adipokines, leptin, vaspin, galectin-3, omentin-1

\section{Introduction}

Adipose tissue is considered an endocrine organ and produces a number of biologically active substances, such as omentin-1, vaspin, and galectin-3, the actions of which have not yet been elucidated. The function of other substances, such as leptin and adiponectin, has been broadly investigated and described over recent years. ${ }^{1-3}$ Galectin-3 is an example of chimera-type galectins - a soluble, beta-galactoside-binding protein produced by the adipose tissue. It participates in various bodily processes, such as cell growth and differentiation, angiogenesis, apoptosis, carcinogenesis. Galectin-3 is also involved in the development of inflammatory processes within fat tissue. Obesity is associated with
Correspondence: Aneta Cymbaluk-Płoska Pomeranian Medical University, Al. Powstańców Wielkopolskich 72,

70-I I I Szczecin, Poland

Tel +48 9l 466 I333

Email anetac@data.pl 
increased levels of macrophages producing Galectin-3, which in turn blocks insulin receptors, leading to insulin resistance. ${ }^{4}$ Omentin- 1 is an adipocytokine excreted by the fat tissue stroma, not by adipocytes. Its secretion is reduced in obesity. It augments insulin-stimulated transmembrane glucose transport and phosphorylation of protein kinase B in adipocytes, suggesting increased insulin sensitivity. Although still poorly understood, it appears similar to adiponectin, an adipokine exhibiting protective properties against metabolic disturbances associated with obesity. Unfortunately, its production and excretion decreases with development of obesity. ${ }^{5}$

In 2005, Hida et $\mathrm{al}^{6}$ identified a new adipocytokine. Serpin, derived from visceral fat, belongs to a family of serine protease inhibitors and is also known as vaspin. Its excretion increases in obesity. Serpins are considered "suicide inhibitors" and the mechanism of protease inhibition may differ from that of other classic inhibitors. It is currently thought that like omentin-1 and adiponectin, vaspin increases the sensitivity of tissues to insulin. ${ }^{6}$

Taking into consideration that obesity as well as type 2 diabetes and associated insulin resistance are well-known risk factors for endometrial cancer, we would like to investigate the association between serum concentrations of adipose tissue metabolism products and the diagnostics and prognosis in endometrial cancer.

\section{Material and methods}

The study included 168 patients with BMI $>20 \mathrm{~kg} / \mathrm{m}^{2}$ admitted due to post-menopausal bleeding. All the patients signed informed consent to participate in the study. The study protocol was approved by the Ethical Committee of the Pomeranian Medical University.
Patients were divided into 3 groups depending on BMI:

1. $\mathrm{BMI}<25, \mathrm{n}=41$ patients

2. BMI $25-30, \mathrm{n}=68$ patients

3. $\mathrm{BMI}>30, \mathrm{n}=59$ patients

BMI was calculated using the following formula:

$$
\mathrm{BMI}=\frac{\text { Weight }[\mathrm{kg}]}{\text { Height }^{2}[\mathrm{~m}]}
$$

Patients were divided into two groups according to the WC index:

1. $\mathrm{WC}<100 \mathrm{~cm}, \mathrm{n}=55$

2. $\mathrm{WC}>100 \mathrm{~cm}, \mathrm{n}=113$

Patients were divided into two groups depending on the presence of type 2 diabetes:

1. $\mathrm{DM}-$ yes, $\mathrm{n}=97$

2. $\mathrm{DM}-\mathrm{no}, \mathrm{n}=71$

The division was also made due to the presence of hypertension. Adopted reference values for HA >140/90 mmHg.

1. HA - yes, $n=129$

2. $\mathrm{HA}-$ no, $\mathrm{n}=39$

Table 1 presents a detailed description of patient allotment.

Material for histopathological examination was taken during procedures including: abrasion, hysteroscopy, and radical surgery in case of confirmed endometrial cancer. Following surgical treatment and the results of histopathological examination patients were assorted into three groups:

1. Patients with endometrial cancer, $n=92$

2. Patients with normal endometrium, $n=44$

3. Patients with endometrial polyps, $n=32$

Table I Examined proteins average concentrations in relation to endometrium cancer risk factors

\begin{tabular}{|c|c|c|c|c|c|}
\hline Risk factor & $\begin{array}{l}\text { Patients } \\
\text { (n) }\end{array}$ & $\begin{array}{l}\text { Leptin (ng/mL), } \\
\text { mean (range) }\end{array}$ & $\begin{array}{l}\text { Galectin-3 }(\mathrm{ng} / \mathrm{mL}) \text {, } \\
\text { mean (range) }\end{array}$ & $\begin{array}{l}\text { Omentin- I (ng/mL), } \\
\text { mean (range) }\end{array}$ & $\begin{array}{l}\text { Vaspin }(\mathrm{ng} / \mathrm{mL}) \text {, } \\
\text { mean (range) }\end{array}$ \\
\hline BMI 20-25 & 41 & $8.2(4.2-12.1)$ & $9.6(0.2-18.2)$ & I,223.2 (342.2-I,789.I) & $2.7(0.1-4.2)$ \\
\hline BMI 25-30 & 68 & $15.9(11.3-22.6)$ & $13.8(6.4-29.6)$ & 498.1 (I23.I-2,453.9) & $3.6(0.4-5.2)$ \\
\hline $\mathrm{BMI}>30$ & 59 & $26.2(19.8-122)$ & $22.4(9.0-113)$ & $168.8(66.4-76 \mid .3)$ & $5.5(2.2-122)$ \\
\hline DM type $2-$ yes & 97 & 19.1 (II.3-22.5) & $19.4(4.8-56.2)$ & $878.8(477.3-I, 221.4)$ & $4.8(1.3-22)$ \\
\hline DM type 2 - no & 71 & $15.2(11.1-18.8)$ & |3.7 (| |.2-3|.2) & $601.3(324.6-1,139.4)$ & $3.1(1.1-23.8)$ \\
\hline$W C<100 \mathrm{~cm}$ & 55 & $11.8(8.1-18.3)$ & $14.4(9.7-23.8)$ & I,442.I (993.I-I,789.3) & $2.9(0.6-19.6)$ \\
\hline$W C>100 \mathrm{~cm}$ & 113 & $20.2(14.4-56.7)$ & $20.1(9.1-38.9)$ & $476.8(101.8-892.1)$ & $4.9(1.2-18.6)$ \\
\hline $\mathrm{PM}<\mathrm{II}$ & 65 & $14.6(9.1-19.9)$ & $12.6(6.7-29.7)$ & $906.5(623.2-1,432.7)$ & $2.6(0.4-6.8)$ \\
\hline$P M>I I$ & 103 & $16.7(12.3-20.9)$ & I5.8 (4.5-33.I) & 782.4 (345.6-932.1) & $3.3(0.9-21.3)$ \\
\hline $\mathrm{HA}-$ yes & 129 & I $3.4(7.5-19.9)$ & I $5.9(8.2-27.1)$ & $872.1(321.2-1,139.3)$ & $3.8(1.4-16.7)$ \\
\hline $\mathrm{HA}-$ no & 39 & I5.I (9.2-20.3) & $16.4(8.8-26.9)$ & $70 I .7$ (333.6-I,002.4) & $2.9(0.9-15.2)$ \\
\hline Nullipara - yes & 33 & $10.2(3.4-16.1)$ & $14.2(7.1-20.6)$ & $567.2(192.4-689.9)$ & $3.3(0.4-18.1)$ \\
\hline Nullipara - no & 133 & I6.4 (8.9-2I.3) & $14.9(1.2-30)$ & $632.5(201.3-I, 134.4)$ & $3.2(0.5-17.6)$ \\
\hline
\end{tabular}

Abbreviations: BMI, body mass index; DM type 2, diabetes mellitus type 2; WC, waist circumference; PM, premenopausal status; HA, arterial hypertension. 
After that, subgroups 2 and 3 were merged to obtain: Group A - Patients with endometrial cancer, $n=92$ Group B - Patients with benign endometrium changes, $n=76$

Among the group of patients with endometrial cancers we identified 80 patients with endometrial endometrioid carcinoma, and 12 patients with non-endometrial endometrioid carcinoma (Table 2).

Patients from the endometrial cancer group were divided according to tumor grading into $\mathrm{G} 1=29, \mathrm{G} 2=41$, and $\mathrm{G} 3=32$ subgroups, as well as depending on clinical tumor staging:

1. FIGO 1 and $2, n=69$ patients

2. FIGO 3 and $4, n=23$ patients

Five milliliters of blood were collected from each patient for protein level determination on the occasion of routine preoperative testing and centrifuged. The serum was subsequently frozen and stored at $-70^{\circ} \mathrm{C}$.

\section{Multiplex immunoassay}

Omentin-1, vaspin, galectin-3, and leptin concentrations were quantified in serum/plasma by multiplex fluorescent bead-based immunoassays (Luminex Corporation, Austin, TX, USA) using commercial Bio Plex Pro RBM Human Metabolic Panel 2 (BioRad, Hercules, CA, USA). Fifty $\mu \mathrm{L}$ of antibody capture bead solution were added to each well of assay plate and the plate was washed two times with $100 \mu \mathrm{L}$ of wash buffer. After washing,

Table 2 Distribution of endometrial cancer patients into subgroups

\begin{tabular}{|c|c|c|}
\hline Subgroups & Distribution & Patients (n) \\
\hline \multirow[t]{2}{*}{$\begin{array}{l}\text { Histopathological } \\
\text { type }\end{array}$} & $\begin{array}{l}\text { Type I cancer (endometrial } \\
\text { endometrioid adenocarcinoma) }\end{array}$ & 80 \\
\hline & $\begin{array}{l}\text { Type II cancer patients (serous } \\
\text { endometrial carcinoma, } \\
\text { squamous adenocarcinoma, and } \\
\text { clear cell carcinoma) }\end{array}$ & 12 \\
\hline \multirow{3}{*}{$\begin{array}{l}\text { Histopathological } \\
\text { grade of the } \\
\text { tumor }\end{array}$} & GI & 29 \\
\hline & G2 & 41 \\
\hline & G3 & 32 \\
\hline \multirow{2}{*}{$\begin{array}{l}\text { Clinical stage of } \\
\text { the tumor }\end{array}$} & FIGO I and II & 69 \\
\hline & FIGO III and IV & 23 \\
\hline \multirow[t]{2}{*}{$\begin{array}{l}\text { Myometrial } \\
\text { infiltration depth }\end{array}$} & $\begin{array}{l}\text { Superficial myometrial } \\
\text { infiltration }(<1 / 2 \text { of the } \\
\text { thickness) }\end{array}$ & 63 \\
\hline & $\begin{array}{l}\text { Deep myometrial infiltration } \\
(>1 / 2 \text { of the thickness) }\end{array}$ & 29 \\
\hline \multirow{2}{*}{$\begin{array}{l}\text { Vascular space } \\
\text { involvement }\end{array}$} & With vascular invasion & 46 \\
\hline & Without vascular invasion & 46 \\
\hline \multirow{2}{*}{$\begin{array}{l}\text { Lymph vessel } \\
\text { involvement }\end{array}$} & With lymph vessel invasion & 33 \\
\hline & Without lymph vessel invasion & 59 \\
\hline \multirow{2}{*}{$\begin{array}{l}\text { Lymph node } \\
\text { metastases }\end{array}$} & With lymph node metastases & 26 \\
\hline & $\begin{array}{l}\text { Without lymph node } \\
\text { metastases }\end{array}$ & 66 \\
\hline
\end{tabular}

Abbreviations: GI-3, grading I-3; FIGO, Fédération Internationale de Gynécologie Obstétrique (International Federation of Gynecology and Obstetrics).
$50 \mu \mathrm{L}$ of each blank, standard and samples were added to the plate, and the plate was incubated with agitation for 1 hour at room temperature and in the dark. After this step, the well was washed with $100 \mu \mathrm{L}$ of wash buffer three times by using a hand-held magnet. Detection antibody cocktail $(25 \mu \mathrm{L})$ was transferred by pipette to each well and the plate was sealed and incubated at room temperature for 30 minutes on a plate shaker.

After washing, $50 \mu \mathrm{L}$ of streptavidin-phycoerythrin mixture was added to the plate and incubated with agitation for 10 minutes in the dark. Finally, after washing, the microspheres in each well were resuspended in $125 \mu \mathrm{L}$ assay buffer and shaken at room temperature for 30 seconds. The plate was then read and analyzed on the Luminex analyzer and analyte concentrations were determined from five different standard curves showing median fluorescence intensity vs protein concentration.

\section{Statistical analysis}

Statistical analysis was performed using Statistica 9.1 PL software. Descriptive characteristics of the examined population of patients were prepared, including the minimum, maximum, mean, and median values. Because the distributions of the study traits were not normal, for evaluation, positional parameters such as median were used. Non-parametric tests with Kruskal-Wallis test and Dunn's post-hoc test for comparisons between three groups were used and Mann-Whitney's $U$-test for comparison between two groups in terms of distribution compatibility of analyzed variables were used.

For the selected groups, the ROC curves were obtained and the AUC was calculated with $95 \%$ confidence intervals according to the nonparametric method by DeLong et al. ${ }^{7}$

Conditional logistic regression, which preserved the matching of cases and controls, was used to estimate the ORs and the $95 \%$ CIs for the associations between the serum omentin-1, vaspin, galectin-3, and leptin levels and the endometrial cancer risk. A $p$-value of $<0.05$ was considered indicative of statistical significance.

\section{Results}

Mean age did not differ between the study groups compared to the controls (52.57 vs 48.70 years). Mean BMI was higher among patients with endometrial cancer compared to the controls, but this result was not statistically significant (30.08 vs $27.45 \mathrm{~kg} / \mathrm{m}^{2}$ ). A greater number of patients with type 2 diabetes was also noted in the group of patients with endometrial cancer $(p=0.02)$.

\section{Study group analysis}

Significantly lower mean omentin- 1 concentrations were noted in obese patients with type 2 diabetes compared 
to mean concentrations observed in obese or overweight patients also with type 2 diabetes. However, patients with $\mathrm{BMI}>30 \mathrm{~kg} / \mathrm{m}^{2}$ exhibited significantly greater mean levels of vaspin and galectin-3 compared to non-obese patients. Statistically significant correlations were also noted between $\mathrm{WC}$ and the levels of galectin-3 and vaspin, amounting to $r=0.77(p=0.002) / r=0.82(p=0.03) / r=0.84(p=0.001)$ respectively.

Statistically significant differences with respect to mean vaspin concentrations were demonstrated between patients with type 2 diabetes and without type 2 diabetes patients ( $4.8 \mathrm{ng} / \mathrm{mL} ; 3.1 \mathrm{ng} / \mathrm{mL}$ respectively). Statistically significant differences were also found between these subgroups for serum concentration of omentin-1, leptin, and galectin-3 $p=0.04 / p=0.002 / p=0.01$, respectively. Results are presented in Table 1.

Mean concentration of galectin-3 protein $(20.9 \mathrm{ng} / \mathrm{mL})$ as well as leptin $(21.3 \mathrm{ng} / \mathrm{mL})$ in group A patients was significantly higher compared to mean concentrations of those proteins among patients from group B (16.3 and $14.6 \mathrm{ng} / \mathrm{mL}$, respectively) (Table 3 and Figure 1).

Comparison of mean galectin-3 levels demonstrated significantly higher concentrations of the protein in the group of patients with endometrial cancer compared to patients with polyp endometrium $(20.9 \mathrm{ng} / \mathrm{mL} ; 14.8 \mathrm{ng} / \mathrm{mL}$, respectively), $p=0.03$. Statistically significant differences were not revealed between mean concentrations of omentin-1, vaspin, galectin-3, and leptin in the group of patients with normal endometrium and mean level of this protein among patients with polyp endometrium. Patients characteristics and average values of tested protein are presented in Table 4.

\section{Comparative analysis based on the presence of risk factors}

Table 2 presents a comparison of serum concentrations of all proteins depending on the presence of prognostic factors. Analysis of currently recognized negative prognostic factors for uterine cancer revealed statistically significant differences between the two types of cancers (endometrial vs non-endometrial) with respect to only two types of proteins: omentin-1 and vaspin. Serum concentrations of galectin-3 showed no differences depending on lymph node involvement. With regard to vaspin, we noted significantly lower serum concentrations in the presence of lymph node involvement ( $p=0.022$ ). Mean leptin levels were significantly greater among patients with lymph vessels involvement ( $p=0.004$ ) compared with the control group. There were also statistically significant differences noted between groups with highly vs poorly differentiated cancers with respect to all studied proteins. Galectin-3 and leptin concentrations were significantly higher in patients with poorly differentiated G3 tumors compared to patients with moderately differentiated G2 tumors, respectively: $p=0.03$ and $p=0.002$ (Table 5). We noted statistically significant differences with respect to all studied proteins in the group of patients with highly differentiated tumors compared to poorly differentiated cancers. Significantly lower values of mean omentin-1 and vaspin concentrations were also demonstrated in cases of lymphatic vessel invasion or deep myometrium infiltration $(p=0.002, p=0.01 / p=0.03, p=0.04$, respectively) (Table 6).

\section{ROC curve analysis and test sensitivity/ specificity evaluation}

In order to evaluate the diagnostic values of leptin, galectin-3, vaspin, and omentin-1, ROC curves were plotted and the areas under the ROC curves (AUC) were calculated.

For leptin and galectin-3, the AUC values were 0.79/0.68, while vaspin and omentin-1, the AUC values were 0.82/0.86 for all study patients.

Diagnostic values of leptin and galectin-3 with regard to differentiation between high (FIGO III and IV) and low (FIGO I and II) stages of clinical tumor advancement and prediction of tumor grading (G1 vs G3) based on the AUC curve presents as follows: $0.82 / 0.70$ and $0.80 / 0.74$. The AUC values for vaspin and omentin-1 with respect to differentiation between histopathological advancement and grading are $0.86 / 0.81$ and $0.83 / 0.77$, respectively. Figures 2 and 3 depict the AUC curves. Table 7 shows sensitivity and specificity values for all proteins.

Table 3 Concentration distribution of examined proteins in endometrium cancer and control group

\begin{tabular}{|c|c|c|c|c|c|c|c|}
\hline \multirow[t]{2}{*}{ Variable } & \multicolumn{3}{|l|}{ Group A } & \multicolumn{3}{|l|}{ Group B } & \multirow[t]{2}{*}{$p$-value } \\
\hline & Patients (n) & Mean (range) & Median $(95 \% \mathrm{CI})$ & Patients (n) & Mean (range) & Median (95\% Cl) & \\
\hline Leptin & 92 & $21.3(0.07-122)$ & $18.45(17-25.3)$ & 76 & $14.6(1.2-52.7)$ & $13.4(13.1-16.1)$ & 0.001 \\
\hline Galectin-3 & 92 & $20.9(2.8-117)$ & $18.8(16-25.2)$ & 76 & $16.3(0.00-86)$ & I3.6 (14.6-23.9) & 0.04 \\
\hline Omentin-I & 92 & $610.1(218.5-13,377)$ & $825(801.3-1,002.6)$ & 76 & I,338.4 (2-4,840) & $1,410.3(1,389.2-1,599.9)$ & 0.002 \\
\hline Vaspin & 92 & $0.6(0.0-10)$ & $0.4(0.0-0.9)$ & 76 & $5.6(0.0-348)$ & $1.8(-2.7-14.9)$ & 0.001 \\
\hline
\end{tabular}



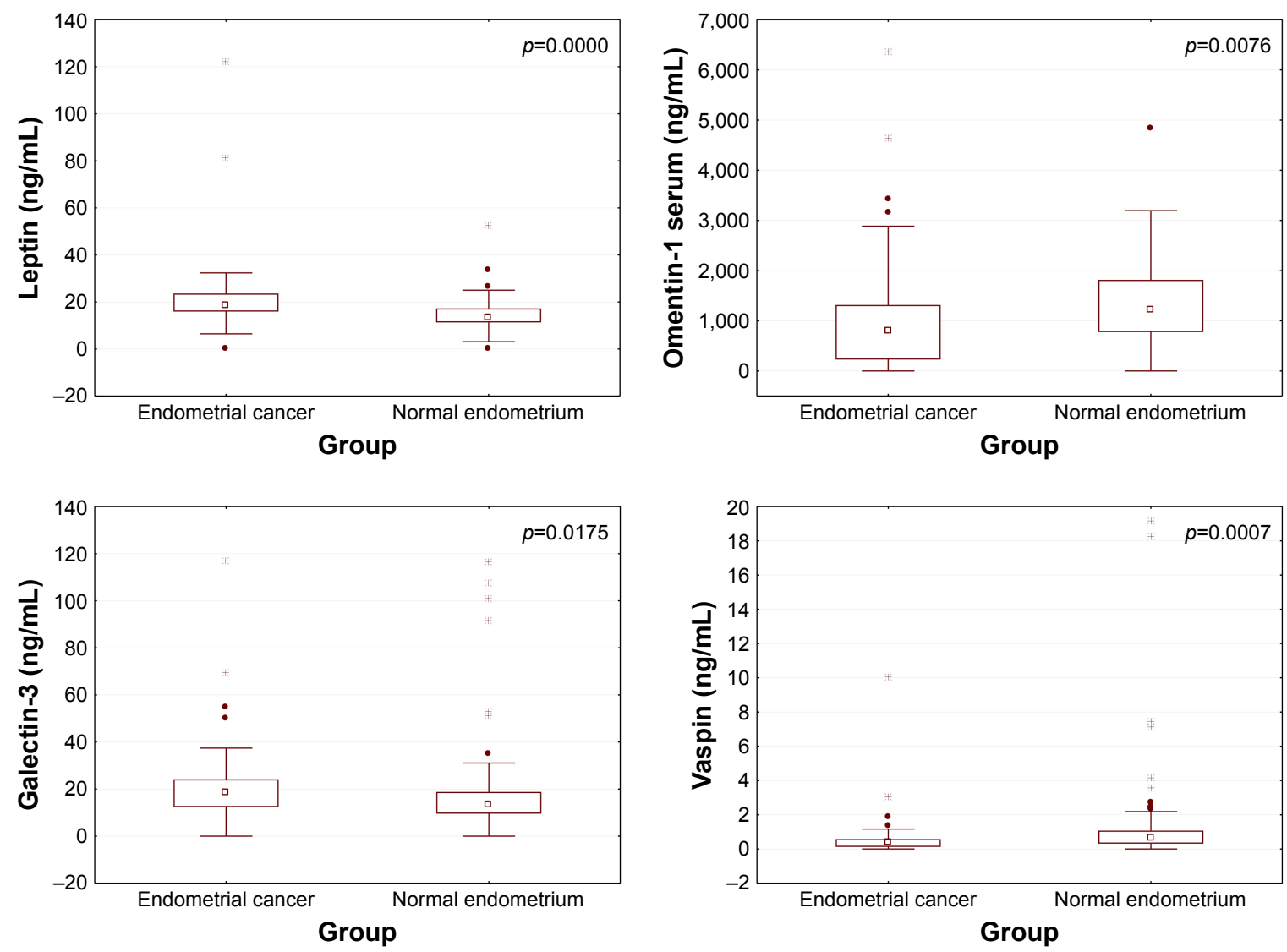

$\square$ Median $\square 25 \%-75 \%$

Figure I Distribution of individual proteins in the study and control groups.

Leptin demonstrated greater sensitivity than specificity in all analyzed patients (84\%/72\%). The greatest sensitivity and specificity was noted for vaspin $(89 \% / 83 \%)$ compared to omentin-1 (85\%/79\%), while galectin-3 was associated with the lowest sensitivity and specificity values $(67 \% / 70 \%)$.

\section{Multivariate logistic regression analysis}

Multivariate logistic regression analysis was used to assess the risk of development of endometrial cancer. The final model identified the following independent risk factors: glucose concentration, BMI, WC, leptin, and vaspin concentrations.

Table 4 Concentrations of individual proteins depending on histopathological diagnosis

\begin{tabular}{|c|c|c|c|c|}
\hline Histopathological diagnosis & Leptin & Galectin-3 & Omentin-I & Vaspin \\
\hline \multicolumn{5}{|l|}{ Endometrial cancer } \\
\hline Mean (range) & $21.3(0.07-122)$ & $20.9(2.8-117)$ & $610.1(218.5-13,377)$ & $0.6(0.0-10)$ \\
\hline Median & 18.45 & 18.8 & 825 & 0.4 \\
\hline \multicolumn{5}{|l|}{ Endometrial polyps } \\
\hline Mean (range) & I $5.7(0.2-34.6)$ & I4.8 (I.3-28.7) & I,I87.5 (432.9-I,786.9) & 4.I $(0.9-22.1)$ \\
\hline Median & 16.1 & 15.2 & $\mathrm{I}, 231 . \mathrm{I}$ & \\
\hline$p$-value & 0.03 & 0.03 & 0.01 & 0.003 \\
\hline \multicolumn{5}{|l|}{ Endometrial cancer } \\
\hline Mean (range) & $21.3(0.07-122)$ & $20.9(2.8-117)$ & $610.1(218.5-13,377)$ & $0.6(0.0-10)$ \\
\hline Median & 18.45 & 18.8 & 825 & 0.4 \\
\hline \multicolumn{5}{|l|}{ Normal endometrium } \\
\hline Mean (range) & I3.3 (0.0-20.I) & $14.3(0.09-22.6)$ & I,354.2 (3।0.7-I,567.2) & $6.7(0.8-348)$ \\
\hline Median & 14.0 & 12.9 & $1,3 \mid 4$ & 5.7 \\
\hline$p$-value & 0.001 & 0.01 & 0.001 & 0.02 \\
\hline
\end{tabular}


Table 5 Concentrations of examined proteins according to clinical stage and histopathological differentiation of cancer

\begin{tabular}{|c|c|c|c|c|}
\hline & $\begin{array}{l}\text { Leptin } \\
\text { (ng/mL) }\end{array}$ & $\begin{array}{l}\text { Galectin-3 } \\
\text { (ng/mL) }\end{array}$ & $\begin{array}{l}\text { Omentin-I } \\
(\mathrm{ng} / \mathrm{mL})\end{array}$ & $\begin{array}{l}\text { Vaspin } \\
\text { (ng/mL) }\end{array}$ \\
\hline \multicolumn{5}{|c|}{ FIGO I and II } \\
\hline Mean & 17.2 & 16.4 & 991.1 & 1.1 \\
\hline Median & 16.6 & 16 & 898.3 & 1.0 \\
\hline Range & $9.6-22.2$ & $2.7-19.3$ & $111.2-1,337$ & $0.2-2.6$ \\
\hline \multicolumn{5}{|c|}{ FIGO III and IV } \\
\hline Mean & 26.3 & 24.4 & 499.5 & 0.52 \\
\hline Median & 24.9 & 25.1 & 567.3 & 0.48 \\
\hline Range & $18.9-122$ & $20.6-25.2$ & $32.7-954.2$ & $0.0-1.4$ \\
\hline$p$-value & 0.02 & 0.01 & 0.4 & 0.3 \\
\hline \multicolumn{5}{|c|}{ Tumor grade I } \\
\hline Mean & 15.1 & 12.3 & 802.5 & 2.6 \\
\hline Median & 16.0 & 11.8 & 776.1 & 2.3 \\
\hline Range & $5.8-19.0$ & $7.6-15.5$ & $200-1,040$ & $0.9-4.0$ \\
\hline \multicolumn{5}{|c|}{ Tumor grade $2^{*}$} \\
\hline Mean & 17.8 & 14.1 & 563.2 & 1.5 \\
\hline Median & 17.1 & 13.9 & 531.3 & 1.3 \\
\hline Range & $|3|-2 \mid .0$. & $0.0-16.1$ & $1 \mid 1.2-1,134$ & $0.4-3.9$ \\
\hline$p$-value & NS & NS & 0.02 & 0.01 \\
\hline \multicolumn{5}{|c|}{ Tumor grade $2^{*}$} \\
\hline Mean & 17.8 & 14.1 & 563.2 & 1.5 \\
\hline Median & 17.1 & 13.9 & 531.3 & 1.3 \\
\hline Range & $|3.1-2| .0$ & $0.0-16.1$ & $1 \mid 1.2-1,134$ & $0.4-3.9$ \\
\hline \multicolumn{5}{|c|}{ Tumor grade 3} \\
\hline Mean & 26.1 & 20.4 & 356.1 & 0.3 \\
\hline Median & 25.1 & 21.1 & 346.8 & 0.2 \\
\hline Range & $11-122$ & 17.4-25.2 & $62.2-667.6$ & $0.0-1.1$ \\
\hline$p$-value & 0.002 & 0.03 & 0.04 & 0.0001 \\
\hline
\end{tabular}

Note: *Tumor grade 2 data is shown twice in order to firstly show the comparision between grade I vs grade 2 and corresponding $p$-values and then show the comparison between grade 2 vs grade 3 and corresponding $p$-values.

Abbreviation: FIGO, Fédération Internationale de Gynécologie Obstétrique.

\section{Discussion}

Obesity is one of the fundamental, if not the most important risk factor for the development of uterine cancer. It is associated with insulin resistance and augmented estrogen production by visceral fat. Other than being a source of estrogens due to aromatization of androstenedione, it secretes a variety of biologically active cytokines.

Leptin is the best-described adipokine. In our study, we assessed serum leptin, as well as galectin-3, omentin-1, and vaspin levels among patients with endometrial cancer. ${ }^{2}$ We noted significantly elevated levels of leptin and galectin-3 in comparison to patients with proper body mass. Leptin levels are tightly correlated with BMI and WC. ${ }^{8}$ Unfortunately, obese patients typically develop insulin resistance as a consequence of damage to the satiety signaling system, leading to accumulation of leptin and chronic hyperleptinemia. The main function of leptin involves regulation of energy balance. ${ }^{9,10}$ It also acts as a mitogen, proinflammatory
Table 6 Distribution of proteins concentrations depending on the stage of patients with endometrium cancer

\begin{tabular}{|c|c|c|c|c|}
\hline & $\begin{array}{l}\text { Leptin } \\
\text { (ng/mL) }\end{array}$ & $\begin{array}{l}\text { Galectin-3 } \\
(\mathrm{ng} / \mathrm{mL})\end{array}$ & $\begin{array}{l}\text { Omentin-I } \\
\text { (ng/mL) }\end{array}$ & $\begin{array}{l}\text { Vaspin } \\
\text { (ng/mL) }\end{array}$ \\
\hline \multicolumn{5}{|c|}{ Endometrial endometrioid carcinoma } \\
\hline Mean & 19.3 & 18.4 & 897.2 & 1.4 \\
\hline Median & 18.9 & 16.2 & 799.1 & 1.2 \\
\hline Range & $11-67.5$ & $0.0-89.5$ & $324.4-1,546$ & $0.2-5.1$ \\
\hline \multicolumn{5}{|c|}{ Non-endometrial endometrioid carcinoma } \\
\hline Mean & 22.9 & 23.7 & 466.3 & 0.4 \\
\hline Median & 24.1 & 21.4 & 404.9 & 1.1 \\
\hline Range & $2.9-122$ & $3.8-46.7$ & |23.4-|,243.8 & $0.0-14.1$ \\
\hline$p$-value & NS & NS & 0.03 & 0.1 \\
\hline \multicolumn{5}{|c|}{ Superficial infiltration of the myometrium } \\
\hline Mean & 16.0 & 17.8 & 777.2 & 1.8 \\
\hline Median & 14.9 & 16.9 & 751.8 & 1.6 \\
\hline Range & I.5-43.6 & $0.8-29.9$ & $225.4-1,098.2$ & $0.1-9.2$ \\
\hline \multicolumn{5}{|c|}{ Deep infiltration of the myometrium } \\
\hline Mean & 27.2 & 26.1 & 367.3 & 0.6 \\
\hline Median & 25.6 & 24.4 & 298.8 & 0.5 \\
\hline Range & $9.3-108$ & $\mathrm{I} . \mathrm{I}-33.8$ & $98.4-723.2$ & $0.0-1.9$ \\
\hline$p$-value & 0.001 & 0.03 & 0.01 & 0.04 \\
\hline \multicolumn{5}{|c|}{ Lymph nodes, metastases - yes } \\
\hline Mean & 23.4 & 28.4 & 401.3 & 0.7 \\
\hline Median & 25.1 & 27.8 & 386.2 & 0.5 \\
\hline Range & $10.4-38.7$ & I. $2-44.2$ & $107.5-651.2$ & $0.2-2.1$ \\
\hline \multicolumn{5}{|c|}{ Lymph nodes, metastases - no } \\
\hline Mean & 15.5 & 24.4 & 523.6 & 2.2 \\
\hline Median & 14.8 & 25.1 & 511.8 & 2.0 \\
\hline Range & $2.9-33.1$ & $8.6-37.2$ & 67.4-987.9 & $0.8-5.2$ \\
\hline$p$-value & 0.01 & NS & NS & 0.02 \\
\hline \multicolumn{5}{|c|}{ Lymph vessel invasion - yes } \\
\hline Mean & 29.8 & 22.1 & 521.2 & 0.5 \\
\hline Median & 25.7 & 23.5 & 508.6 & 0.4 \\
\hline Range & II.I-58.4 & $3.5-39.2$ & |23.4-999.2 & $0.0-1.2$ \\
\hline \multicolumn{5}{|c|}{ Lymph vessel invasion - no } \\
\hline Mean & 17.8 & 20.3 & 897.4 & 1.2 \\
\hline Median & 15.9 & 19.8 & 756.9 & 1.2 \\
\hline Range & $0.4-122$ & I.8-55.4 & $89.8-1,324$ & $0.3-3.4$ \\
\hline$p$-value & 0.004 & NS & 0.002 & 0.03 \\
\hline
\end{tabular}

Abbreviation: NS, not significant.

and proangiogenic factor that induces neoplastic cell proliferation and angiogenesis. Recent studies suggest that leptin/leptin (Ob-R) receptor modulation may affect the development of many different malignant tumors by activating the PI3K, MAPK, and STAT3 pathways, including endometrium cancer. ${ }^{11}$ Leptin induces macrophages to produce key inflammatory cytokines, ie, tumor necrosis factor (TNF) $\alpha$ and interleukin 6. Chronic inflammation in overweight patients with metabolic syndrome and associated hyperinsulinemia seems to have a key influence on the endometrium cancer proliferation process in obese patients. $^{3}$ 


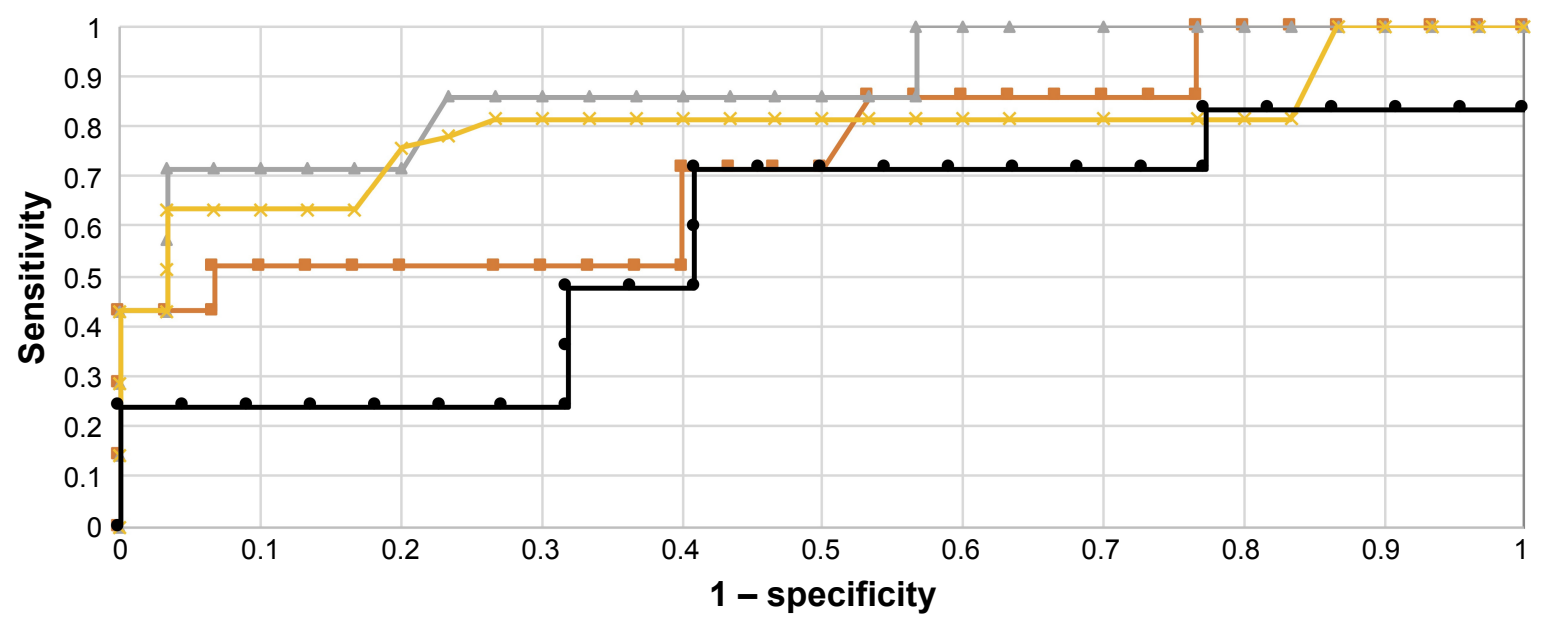

$\rightarrow$ Leptin $\rightarrow$ Omentin-1 $\rightleftharpoons$ Vaspin $\rightarrow$ Galectin-3

Figure $\mathbf{2}$ The receiver operating characteristic curves for proteins in endometrial cancer and benign endometrial changes.

Our study showed higher leptin levels among patients with endometrial cancer (naturally, patient weight was taken into consideration). Other authors report similar results..$^{12,13}$ In our study conducted in 2007 we noted elevated leptin levels not only in patients with endometrial cancer, but also in those with pathological endometrial hypertrophy, ie, precancerous states..$^{14}$ Moreover, in the current study, we report significantly elevated leptin levels among patients with higher staging of endometrial cancer and with a lower degree of histopathological differentiation. We also found a relationship between leptin concentrations and infiltration of lymphatic vessels and presence of lymph node metastases. In their meta-analysis, Wang et al ${ }^{15}$ concluded that elevated leptin concentration might constitute an independent risk factor for endometrial cancer. Zhou et al ${ }^{16}$ obtained similar results on endometrial cancer cell lines, reporting greater leptin expression in poorly differentiated endometrial cancer cells. In this present study, leptin caused partial inhibition of apoptosis through activation of the NIK/IKK pathway. Some studies, for example, the Zhou et al study, report overexpression of leptin receptor $\mathrm{Ob}-\mathrm{Rb}$ in endometrial cancer. ${ }^{16}$

In our studies, we also found increased levels of galectin-3 among patients with endometrial cancer accompanied by great variations in its concentration, related to the degree of tumor advancement. Galectin-3, present as a monomer, but capable of forming multimers, interacts with extracellular matrix especially the group of metalloproteinases. ${ }^{17,18}$ Involvement of numerous metalloproteinases in the progression of endometrial cancer has been confirmed. Our research team has broadly investigated metalloproteinases, including MMP-2

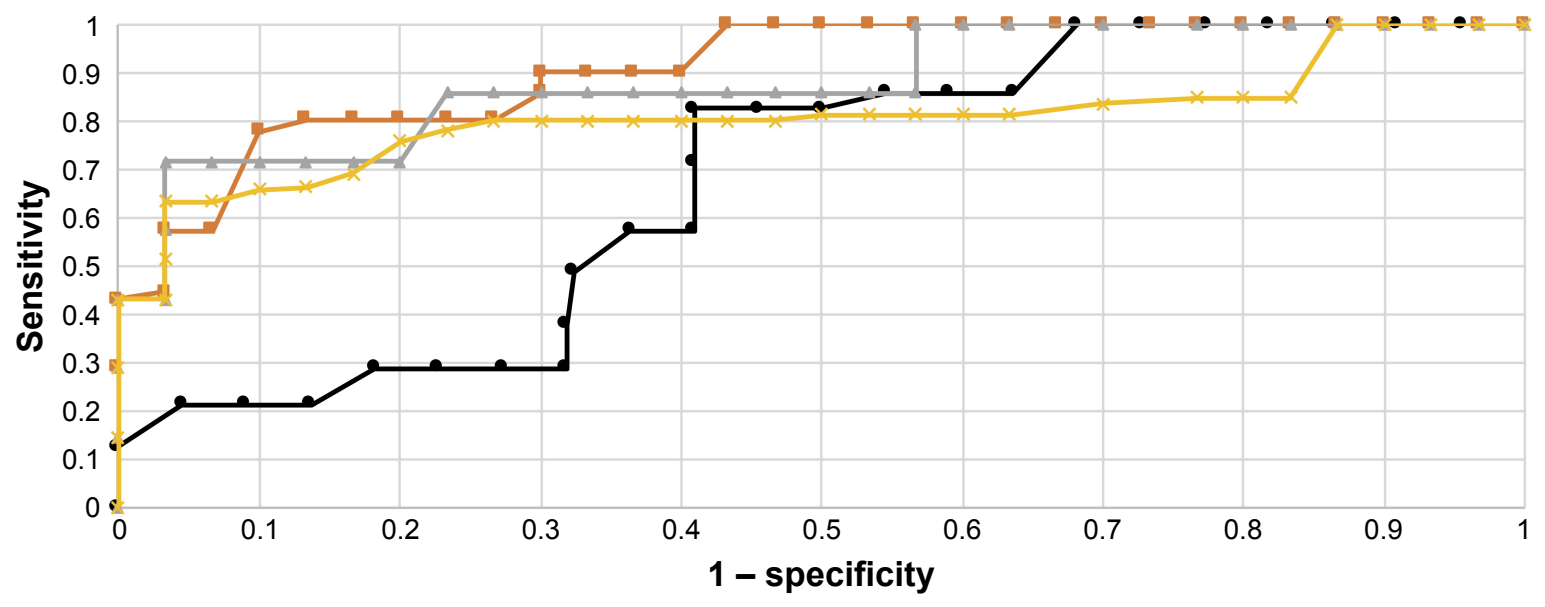

- Galectin-3 Omentin-1 $\simeq$ Leptin $\cong$ Vaspin

Figure 3 The receiver operating characteristic curves for proteins depending on stage of the cancer. 
Table 7 Sensitivity and specificity for leptin, galectin-3, omentin- I, and vaspin

\begin{tabular}{|l|l|l|l|l|}
\hline & Leptin & Galectin-3 & Omentin-I & Vaspin \\
\hline Sensitivity & $84 \%$ & $67 \%$ & $85 \%$ & $89 \%$ \\
\hline Specificity & $72 \%$ & $70 \%$ & $79 \%$ & $83 \%$ \\
\hline
\end{tabular}

and MMP-9. ${ }^{19}$ Their serum levels increase significantly with tumor advancement. Elevated tissue expression of galectin-3 has been described in a number of neoplasms, including breast, stomach, prostate, and CNS cancers. ${ }^{20-24}$ The role of galectin-3 as a protein influencing tumor size, proliferation of neoplastic cell lines and increasing metastatic potential, eg, in in breast cancer, has been emphasized. ${ }^{25}$ The antiapoptotic properties of galectin-3 also seem to be well described. ${ }^{26}$ By analyzing the literature, we came to the conclusion that galectin-3 aids endometrial cancer invasion by directly influencing neoangiogenesis, ${ }^{27,28}$ and also through induction of extracellular metalloproteinases and enabling neoplastic cell adhesion to vascular endothelium, which facilitates migration and formation of distant metastases. ${ }^{29}$

In our studies, we noted a correlation between serum vaspin concentration, BMI, and type 2 diabetes. Yang et al reported similar results, ${ }^{30}$ stressing the association between serum vaspin levels and BMI, WC, and the amount of visceral adipose tissue. He suggested that in the elderly vaspin might play a protective role against development of type 2 diabetes. According to other publications, vaspin improves tissue insulin sensitivity ${ }^{31}$ and inhibits inflammatory processes in vascular endothelium. ${ }^{32,33}$

However, there are also some reports in the literature negating the association between serum vaspin concentrations and BMI. ${ }^{34,35}$ In our study, significantly lower vaspin levels were noted in the sera of patients with endometrial cancer. Considering the role of vaspin as a factor that augments tissue sensitivity to insulin, protecting against one of the risk factors for endometrial cancer associated with obesity, it appears that low concentrations of vaspin would increase the risk of endometrial cancer development. Similar results, although on smaller group of patients, were reported by Erdogan et al, ${ }^{36}$ who found reduced serum concentrations of two proteins - vaspin and adiponectin, among patients with endometrial cancer. Researchers underscore the protective action of those two adipocytokines in obese patients, presenting four hormonal pathways of carcinogenesis associated with obesity: hyperestrogenism, hypoprogesteronism, hyperinsulinemia, and hyperleptinemia, where both vaspin and adiponectin play important roles.

Chronic hyperinsulinemia is one of the main risk factors for endometrial cancer, as insulin exhibits mitogenic and proliferative action through endometrial insulin receptors. ${ }^{3}$ Moreover, chronic hyperinsulinemia may lead to hyperandrogenism and, in obesity, androgen aromatization to estrogens, which have been linked to proliferation in endometrial cancer, particularly among post-menopausal women. ${ }^{2}$ In our study, we also demonstrated the relationship between low serum vaspin concentration and greater degree of clinical advancement of endometrial cancer. We cannot compare our results with other reports, since the association between serum vaspin concentration and FIGO stage has not been studied to date. We may, however, attempt to explain the mechanism of this association. In hyperglycemia, vaspin attenuates phosphorylation of insulin receptor and its product, resulting in inhibition of insulin receptor (IRS2) activity. This is a mechanism of protection against tissue hyperinsulinemia. ${ }^{37}$ Vaspin has been shown to reduce proliferation and chemokinesis of vascular smooth muscle by blocking insulin receptor signaling and the NF- $\kappa B$ signaling pathway. ${ }^{4}$ Also, in vitro studies reveal that it prevents neoangiogenesis by blocking the activation of reactive oxygen species and pathways MAPK and PI3K/Akt. ${ }^{38}$

Our study demonstrated significantly reduced levels of omentin-1 among patients with elevated BMI and type 2 diabetes. This is in agreement with the results reported by Escote et al, who also found a negative correlation between serum omentin-1 concentration and BMI, WC, body fat content, and fasting serum insulin levels. According to the reports of those authors, physical exercise and body mass reduction led to increase in serum omentin-1 levels. Other studies failed to find changes in omentin-1 levels among overweight patients subjected to regular aerobic exercise. ${ }^{39}$ However, most authors emphasize that omentin-1 improves tissue insulin sensitivity, also among type 2 diabetes patients. ${ }^{5}$ Low levels of omentin-1 may be associated with systemic inflammation characteristic for obesity, attracting other interleukins and chemotactic factors. Our studies showed significantly reduced serum omentin- 1 concentrations among patients with endometrial cancer as well as a correlation between serum omentin-1 and cancer staging. We were not able to find any studies in the literature relating to omentin-1 concentrations among patients with endometrial cancer. However, taking into consideration the main risk factors for the development of this type of cancer, which are tightly correlated to the studied protein, our results seem to corroborate the protective function of omentin-1 in increasing insulin sensitivity as well as its indirect anti-carcinogenic action. AminiLari et al ${ }^{40}$ demonstrated that 12 weeks of aerobic exercise resulted in better insulin resistance profile among studied patients (HOMA1 R), which was associated 
with increased serum concentrations of omentin-1. It seems that maintaining healthy body mass and improving insulin sensitivity should become the key preventive measures against development of endometrial cancer. It should be remembered that in developed countries the incidence of endometrial cancer grows each year, with increasing rates of obesity and associated metabolic syndrome. ${ }^{41}$

\section{Conclusion}

Elevated concentrations of leptin, vaspin, and omentin-1 may indicate the presence of endometrial cancer. Leptin and vaspin appear to be useful tools in the assessment of clinical staging of endometrial cancer.

\section{Abbreviations}

AUC, area under the curve; BMI, body mass index; CNS, central nervous system; DM type 2, diabetes mellitus type 2; FIGO, Fédération Internationale de Gynécologie Obstétrique (International Federation of Gynecology and Obstetrics); G1-3, tumor grading 1-3; HA, arterial hypertension; HE4, human epididymis protein 4; HOMA $1 \mathrm{R}$, index in identifying insulin resistance; IRS-2, type-2 insulin receptor substrate; MMP2, matrix metalloproteinase type 2; ROC, receiver operating characteristic; WC, waist circumference.

\section{Acknowledgments}

Ethical approval was provided by the Ethical Committee of the Pomeranian Medical University in Szczecin (resolution number: KB-0012/77/12; 13 October 2012). All procedures performed in studies involving human participants were in accordance with the ethical standards of the institutional Ethical Committee and with the 1964 Helsinki declaration and its later amendments. Written informed consent was provided by the patients as well as the physician. All the patients signed informed consent for the study, which was signed and initialed by the doctor on each page of the consent form. Patients carefully read the information and were able to ask questions.

\section{Disclosure}

The authors report no conflicts of interest in this work.

\section{References}

1. Hossein-Nezhad A, Mirzaei K, Ansar H, Emam-Gholipour S, Tootee A, Keshavarz SA. Obesity, inflammation and resting energy expenditure: possible mechanism of progranulin in this pathway. Minerva Endocrinol. 2012;37(3):255-266.

2. Ouchi N, Parker JL, Lugus JJ, Walsh K. Adipokines in inflammation and metabolic disease. Nat Rev Immunol. 2011;11(2):85-97.

3. Shaw E, Farris M, McNeil J, Friedenreich C. Obesity and endometrial cancer. Recent Results Cancer Res. 2016;208:107-136.
4. Li P, Liu S, Lu M, et al. Hematopoietic-derived galectin-3 causes cellular and systemic insulin resistance. Cell. 2016;167(4):973.e12-984.e12.

5. Zhou JY, Chan L, Zhou SW. Omentin: linking metabolic syndrome and cardiovascular disease. Curr Vasc Pharmacol. 2014;12(1):136-143.

6. Hida K, Wada J, Eguchi J, et al. Visceral adipose tissue-derived serine protease inhibitor: a unique insulin-sensitizing adipocytokine in obesity. Proc Natl Acad Sci U S A. 2005;102(30):10610-10615.

7. DeLong ER, DeLong DM, Clarke-Pearson DL. Comparing the areas under two or more correlated receiver operating characteristic curves: a nonparametric approach. Biometrics. 1988;44(3):837-845.

8. Al Maskari MY, Alnaqdy AA. Correlation between serum leptin levels, body mass index and obesity in Omanis. Sultan Qaboos Univ Med J. 2006;6(2):27-31.

9. Jéquier E. Leptin signaling, adiposity, and energy balance. Ann NY Acad Sci. 2002;967:379-388.

10. Rosenbaum M, Leibel RL. 20 years of leptin: role of leptin in energy homeostasis in humans. J Endocrinol. 2014;223(1):T83-T96.

11. Gao J, Tian J, Lv Y, et al. Leptin induces functional activation of cyclooxygenase-2 through JAK2/STAT3, MAPK/ERK, and PI3K/ AKT pathways in human endometrial cancer cells. Cancer Sci. 2009; 100(3):389-395.

12. Ma Y, Liu Z, Zhang Y, Lu B. Serum leptin, adiponectin and endometrial cancer risk in Chinese women. J Gynecol Oncol. 2013;24(4): 336-341.

13. Petridou E, Belechri M, Dessypris N, et al. Leptin and body mass index in relation to endometrial cancer risk. Ann Nutr Metab. 2002. 46(3-4):147-151.

14. Cymbaluk A, Chudecka-Glaz A, Rzepka-Gorska I. Leptin levels in serum depending on body mass index in patients with endometrial hyperplasia and cancer. Eur J Obstet Gynecol Reprod Biol. 2008; 136(1):74-77.

15. Wang PP, He XY, Wang R, Wang Z, Wang YG. High leptin level is an independent risk factor of endometrial cancer: a meta-analysis. Cell Physiol Biochem. 2014;34(5):1477-1484.

16. Zhou X, Li H, Chai Y, Liu Z. Leptin inhibits the apoptosis of endometrial carcinoma cells through activation of the nuclear factor kappaBinducing kinase/IkappaB kinase pathway. Int J Gynecol Cancer. 2015; 25(5):770-778.

17. Siwicki M, Engblom C, Pittet MJ. Gal3 links inflammation and insulin resistance. Cell Metab. 2016;24(5):655-656.

18. Yu Q, Shen W, Zhou H, Dong W, Gao D. Knockdown of LI-cadherin alters expression of matrix metalloproteinase-2 and -9 and galectin-3. Mol Med Rep. 2016;13(5):4469-4474.

19. Cymbaluk-Ploska A, Chudecka-Glaz A, Pius-Sadowska E, et al. Clinical importance of serum HE4 and MMP2 levels in endometrial cancer patients. Onco Targets Ther. 2017;10:3169-3175.

20. Guha P, Kaptan E, Bandyopadhyaya G, et al. Cod glycopeptide with picomolar affinity to galectin-3 suppresses T-cell apoptosis and prostate cancer metastasis. Proc Natl Acad Sci U S A. 2013;110(13): 5052-5057.

21. Shekhar MP, Nangia-Makker P, Tait L, Miller F, Raz A. Alterations in galectin-3 expression and distribution correlate with breast cancer progression: functional analysis of galectin-3 in breast epithelialendothelial interactions. Am J Pathol. 2004;165(6):1931-1941.

22. Wang L, Guo XL. Molecular regulation of galectin-3 expression and therapeutic implication in cancer progression. Biomed Pharmacother. 2016;78:165-171.

23. Park SH, Min HS, Kim B, Myung J, Paek SH. Galectin-3: a useful biomarker for differential diagnosis of brain tumors. Neuropathology. 2008;28(5):497-506.

24. Zhu WQ, Ochieng J. Rapid release of intracellular galectin-3 from breast carcinoma cells by fetuin. Cancer Res. 2001;61(5):1869-1873.

25. Miyazaki J, Hokari R, Kato S, et al. Increased expression of galectin-3 in primary gastric cancer and the metastatic lymph nodes. Oncol Rep. 2002;9(6):1307-1312.

26. Fukumori T, Oka N, Takenaka Y, et al. Galectin-3 regulates mitochondrial stability and antiapoptotic function in response to anticancer drug in prostate cancer. Cancer Res. 2006;66(6):3114-3119. 
27. Jia W, Kidoya H, Yamakawa D, Naito H, Takakura N. Galectin-3 accelerates M2 macrophage infiltration and angiogenesis in tumors. Am J Pathol. 2013;182(5):1821-1831.

28. Nangia-Makker P, Honjo Y, Sarvis R, et al. Galectin-3 induces endothelial cell morphogenesis and angiogenesis. Am J Pathol. 2000;156(3): 899-909.

29. Nakajima K, Kho DH, Yanagawa T, et al. Galectin-3 cleavage alters bone remodeling: different outcomes in breast and prostate cancer skeletal metastasis. Cancer Res. 2016;76(6):1391-1402.

30. Yang L, Chen SJ, Yuan GY, Wang D, Chen JJ. Changes and clinical significance of serum vaspin levels in patients with type 2 diabetes. Genet Mol Res. 2015;14(3):11356-11361.

31. Blüher M. Vaspin in obesity and diabetes: pathophysiological and clinical significance. Endocrine. 2012;41(2):176-182.

32. Yang W, Li Y, Tian T, Wang L. Serum vaspin concentration in elderly type 2 diabetes mellitus patients with differing body mass index: a crosssectional study. Biomed Res Int. 2017;2017:4875026.

33. Phalitakul S, Okada M, Hara Y, Yamawaki H. Vaspin prevents methylglyoxal-induced apoptosis in human vascular endothelial cells by inhibiting reactive oxygen species generation. Acta Physiol (Oxf). 2013;209(3):212-219.

34. Aust G, Richter O, Rohm S, et al. Vaspin serum concentrations in patients with carotid stenosis. Atherosclerosis. 2009;204(1): 262-266.
35. Seeger J, Ziegelmeier M, Bachmann A, et al. Serum levels of the adipokine vaspin in relation to metabolic and renal parameters. J Clin Endocrinol Metab. 2008;93(1):247-251.

36. Erdogan S, Sezer S, Baser E, et al. Evaluating vaspin and adiponectin in postmenopausal women with endometrial cancer. Endocr Relat Cancer. 2013;20(5):669-675.

37. Li K, Li L, Yang M, et al. Short-term continuous subcutaneous insulin infusion decreases the plasma vaspin levels in patients with type 2 diabetes mellitus concomitant with improvement in insulin sensitivity. Eur J Endocrinol. 2011;164(6):905-910.

38. Li H, Peng W, Zhuang J, et al. Vaspin attenuates high glucose-induced vascular smooth muscle cells proliferation and chemokinesis by inhibiting the MAPK, PI3K/Akt, and NF-kappaB signaling pathways. Atherosclerosis. 2013;228(1):61-68.

39. Faramarzi M, Banitalebi E, Nori S, Farzin S, Taghavian Z. Effects of rhythmic aerobic exercise plus core stability training on serum omentin, chemerin and vaspin levels and insulin resistance of overweight women. J Sports Med Phys Fitness. 2016;56(4):476-482.

40. AminiLari Z, Fararouei M, Amanat S, et al. The effect of 12 weeks aerobic, resistance, and combined exercises on omentin-1 levels and insulin resistance among type 2 diabetic middle-aged women. Diabetes Metab J. 2017;41(3):205-212.

41. Jemal A, Siegel R, Ward E, Hao Y, Xu J, Thun MJ. Cancer statistics, 2009. CA Cancer J Clin. 2009;59(4):225-249.
OncoTargets and Therapy

\section{Publish your work in this journal}

OncoTargets and Therapy is an international, peer-reviewed, open access journal focusing on the pathological basis of all cancers, potential targets for therapy and treatment protocols employed to improve the management of cancer patients. The journal also focuses on the impact of management programs and new therapeutic agents and protocols on

\section{Dovepress}

patient perspectives such as quality of life, adherence and satisfaction The manuscript management system is completely online and includes a very quick and fair peer-review system, which is all easy to use. Visit http://www.dovepress.com/testimonials.php to read real quotes from published authors. 